\title{
Evolution of Chilean colonizing populations of Drosophila subobscura: lethal genes and chromosomal arrangements
}

\author{
Francesc Mestres · Joan Balanyà · Marta Pascual • \\ Concepció Arenas · George W. Gilchrist • \\ Raymond B. Huey $\cdot$ Luís Serra
}

Received: 28 March 2008/ Accepted: 14 July 2008

(c) Springer Science+Business Media B.V. 2008

\begin{abstract}
Knowledge of the frequency, distribution, and fate of lethal genes in chromosomal inversions helps to illuminate the evolution of recently founded populations. We analyze the relationship between lethal genes and inversions in two colonizing populations of D. subobscura in Chile. In the ancestral Palearctic populations of this species, lethal genes seem distributed at random on chromosomes. But in colonizing American populations, some lethal genes are associated with specific chromosomal arrangements. Some of these associated lethals were detected only during the first stages of the colonization $\left(\mathrm{O}_{\underline{3+4}+2}\right)$, and never thereafter, whereas others have persisted $\left(\mathrm{O}_{\underline{3+4}+\underline{7}}\right.$ and $\left.\mathrm{O}_{5}\right)$. However, most lethal genes in American populations have been observed only once: they have arisen by novel mutation and soon disappear. Finally, recombination between different inversions has been observed in America. However, the persistence of lethal
\end{abstract}

Electronic supplementary material The online version of this article (doi:10.1007/s10709-008-9298-y) contains supplementary material, which is available to authorized users.

F. Mestres $(\bowtie) \cdot$ J. Balanyà $\cdot$ M. Pascual $\cdot$ L. Serra Departament de Genètica, Facultat de Biologia, Universitat de Barcelona, Av. Diagonal, 645, 08028 Barcelona, Spain e-mail: fmestres@ub.edu

C. Arenas

Departament d'Estadística, Facultat de Biologia, Universitat de Barcelona, Av. Diagonal, 645, 08028 Barcelona, Spain

G. W. Gilchrist

Department of Biology, College of William and Mary, Box 8795, Williamsburg, VA 23187, USA

R. B. Huey

Department of Biology, University of Washington, Box 351800,

Seattle, WA 98195-1800, USA genes associated with the heterotic inversions $\mathrm{O}_{\underline{3+4}+\underline{7}}$ and $\mathrm{O}_{5}$ could indicate that recombination inside these inversions is rare.

Keywords D. subobscura - Colonization - Lethal genes · Chromosomal inversions · Association $\cdot$ Heterosis

\section{Introduction}

The use of lethal genes to study the genetic structure of natural populations was pioneered by Dobzhansky and Wright (Dobzhansky and Wright 1941; Wright et al. 1942). For example, the high frequency of lethal genes is likely an indicator of centrality versus marginality of populations (Townsend 1952; Sperlich et al. 1977; Brussard 1984; Krimbas 1993). This may be due to the fact that in small (i.e., marginal) populations lethal genes are purged at a faster rate because of inbreeding. However, frequencies of lethal genes on the $\mathrm{O}$ chromosome of $D$. subobscura in its native range are higher than expected in several marginal populations, and these frequencies display a wide range of variation (Sperlich et al. 1977; Loukas et al. 1980; Pfriem and Sperlich 1982; Mestres et al. 1990; Saura et al. 1990, 1998; Zivanovic et al. 2000). In contrast, observed frequencies of lethal genes are low in colonizing populations of D. subobscura in America, reflecting the founder event (Mestres et al. 1990, 1992, 1995; Solé et al. 2000).

In addition to determining the frequency of lethal genes, it is also useful to know how many copies of a specific lethal gene (i.e., alleles identical by descent) exist in a population. This information can be obtained through an allelism test. A few studies have analyzed lethal allelism in Paleactic populations of D. subobscura. Loukas et al. (1980) found low frequencies of this allelism in 
populations on Mt. Parnes (Greece) and Alikianou (in the Greek island of Crete), probably because these big populations were collected during their expansion period. Low frequency of allelism was also found in Bordils population (NE of Spain), but in this case the chromosomal composition for inversions was known for each pair of allelic lethal lines (Mestres et al. 1990). Only one of five cases of allelism was produced by a pair of lines carrying the same chromosomal arrangement. Thus, most of these lethal genes were not associated with chromosomal arrangements. Finally, three Balkan populations of D. subobscura (two from Serbian and one from Montenegro) were studied for the lethal allelism. Only one of them had a high frequency of lethal alleles, and none of the populations showed an association between lethals and chromosomal arrangements (Zivanovic et al. 2000).

Most information on lethals of this species has been gathered on the American colonizing populations (Mestres et al. 1990, 1992, 1995; Solé et al. 2000). In all American populations studied so far, a lethal gene is always associated with the $\mathrm{O}_{5}$ inversion. In fact, this lethal gene is found only in the chromosomes carrying this inversion, and this inversion always carries this lethal. Another lethal gene is associated with the $\mathrm{O}_{\underline{3+4+1}}$ arrangement. Although this lethal is found only in this arrangement, not all $\mathrm{O}_{\underline{3+4+7}}$ chromosomes carry this lethal: some have normal viability, and others carry different lethal genes. Finally, another lethal gene is similarly incompletely associated with the $\mathrm{O}_{\underline{3+4}+\underline{2}}$ arrangement. These three associations between lethals and inversions have been found in both hemispheres of the Americas, indicating that the North and South American populations were derived from the same original colonizing sample (Mestres et al. 1992), and they are, most probably, a consequence of the founder event. The complete association with the $\mathrm{O}_{5}$ inversion and the incomplete association with the $\mathrm{O}_{\underline{3+4+7}}$ arrangement have probably persisted because a heterotic effect of the inversions (Mestres et al. 2001).

Initial surveys for lethal genes in the Chilean populations were based on a sample of Santiago de Chile collected in 1988 ("Santiago de Chile I"), about one decade after the colonization. We collected new samples of D. subobscura from two populations in Chile in 1999, thus two decades after the initial invasion. Our main aims were to continue monitoring the evolution of the associations of lethal genes and chromosomal inversions in colonizing populations, to learn whether previously observed lethal genes persist, and to determine whether new lethals and associations might have evolved since the last samples. We studied Puerto Montt $\left(41^{\circ} 28^{\prime} \mathrm{S}\right)$, because it was the first South American locality where D. subobscura was detected in America (Brncic et al. 1981). We also studied flies from Santiago de Chile ( $33^{\circ} 30^{\prime} \mathrm{S}$, "Santiago de Chile II"), which is far from Puerto Montt (see below) and has a different composition of chromosomal arrangements (Prevosti et al. 1985, 1988, 1990; Balanyà et al. 2003). We analyzed intra-populational lethal allelism of these two populations as well as their inter-populational allelism. We also compared inter-populational allelism of each of these two populations with four additional American populations that had been analyzed previously (Mestres et al. 1990, 1992, 1995; Solé et al. 2000).

\section{Materials and methods}

Populations

We analyzed genetic data from two South American populations (Santiago de Chile II and Puerto Montt), sampled in October and November 1999, respectively. Puerto Montt is located about $900 \mathrm{~km}$ south of Santiago de Chile. We compared these data with those collected from Santiago de Chile I, sampled in December 1988 (Mestres et al. 1992) and with some $\mathrm{O}_{5}$ lethal chromosomal lines from Puerto Montt, sampled in 1986 (Mestres et al. 1990). We made additional comparisons with lethal gene data from four North American populations: Gilroy I (October 1984 and April 1985) (Mestres et al. 1990), Gilroy II (October 1990 and April 1991), Bellingham (September 1991) (Mestres et al. 1992), and Centralia (October 1995) (Solé et al. 2000). Gilroy is in California (USA), while Centralia and Bellingham are located far north in Washington (USA).

\section{Chromosome extraction and allelism tests}

Crosses of wild-caught flies with chcu (cherry curled, homokaryotypic strain) and $\mathrm{Va} / \mathrm{Ba}$ (Varicose/Bare, lethal balanced strain) strains were made for obtaining chromosomes in homozygous condition (Mestres et al. 1990). Chromosomes carrying lethals were maintained in heterozygous condition with the $V a$ balancer chromosome. $V a$ lines heterozygous for wild lethal-carrying chromosomes were intercrossed to ascertain whether the lethal genes were allelic. All possible intra-populational allelism crosses were carried out for the Santiago de Chile II and Puerto Montt populations. Inter-populational allelism tests were also carried out between both populations and with Gilroy (I and II), Bellingham, and Centralia. Finally, all lethal chromosomes from Santiago de Chile II and Puerto Montt were also tested against old lethal chromosomal lines from Santiago de Chile $\mathrm{I}$ and against several $\mathrm{O}_{5}$ lethal chromosomal lines from Puerto Montt, as well as against the $\mathrm{O}_{5}$ lethal chromosomal line from Taulé (France) (Mestres et al. 1992).

The $V a$ balancer chromosome carries two (X-ray induced) overlapping inversions (named $\mathrm{O}_{\mathrm{VIII}+210}$ ) plus the 
naturally occurring arrangement $\mathrm{O}_{3+4}$. About two-thirds of the $\mathrm{O}$ chromosome (segment SII) is covered by the $\mathrm{O}_{\text {VIII }+210}$ inversions; most of the rest (segment SI) is covered by the $\mathrm{O}_{\underline{3+4}}$ arrangement. Thus, if a wild chromosome carries the $\mathrm{O}_{\underline{3+4}}$ arrangement without any overlapping inversions, crossing over is not prevented between the wild and the $V a$ balancer chromosomes. In a previous study, the magnitude of recombination was not trivial (Mestres et al. 1990). Thus, lethal genes located on the SI segment of $\mathrm{O}_{\underline{3+4}}$ wild chromosomes can be lost through recombination: consequently, only those lethals present within the SII segment can be ascertained. However, the whole chromosome (segments SI + SII) can be assayed in wild chromosomes lacking the $\mathrm{O}_{\underline{3+4}}$ arrangement. We have used Loukas et al.'s (1980) correction, which transforms the SI + SII lethal chromosomes into SII lethal "equivalents." All laboratory strains, stocks and crosses were kept at $18^{\circ} \mathrm{C}$ in standard Drosophila cultures.

\section{Statistical methods}

The distribution of lethal genes along the $\mathrm{O}$ chromosome of D. subobscura was analyzed assuming a Poisson distribution. If lethal genes were randomly distributed along the $\mathrm{O}$ chromosome, a value of $k$ (defined as the proportion of lethal genes in segment SII with respect to the whole chromosome) close to $2 / 3$ would be expected. The significance of $k$ values was obtained with a maximum likelihood approach, using the Wilks' approximation.

$-2 \ln \Lambda \approx \chi^{2}$

with one degree of freedom (Mestres and Serra 1999).

Effective population size $\left(N_{\mathrm{e}}\right)$ was estimated as described by Nei (1968) and also by Begon et al. (1985): both methods gave very similar values. Lethal heterozygote fitness reduction was estimated following Crow and Temin (1964) and Nei (1968). However, all these estimates are tentative, as the incidence of lethal genes is not in equilibrium in the American populations.

To compare the chromosomal polymorphism of lethal versus non-lethal arrangements, we carried out a principal component analysis for 11 populations, each divided into two samples (non-lethal and lethal chromosomes): Kamariste (K and KL), Zanjic (Z and ZL), Petnica (P and PL), Djerdap I (DI and DIL) (collected in 2001) and Djerdap II (DII and DIIL) (collected in 2002) from the Palearctic region (Zivanovic et al. 2000; Zivanovic and Marinkovic 2003) and Santiago de Chile II (SC and SCL), Puerto Montt (PM and PML), Gilroy I (GI and GIL), Gilroy II (GII and GIIL), Centralia (C and CL), and Bellingham (B and BL) (Prevosti et al. 1988; Mestres et al. 1990, 1992, 1995; Solé et al. 2000; Balanyà et al. 2003) from the Americas. Overall, a total of 14 different arrangements have been observed.
Each sample $\left(P_{i}, i=1, \ldots, 22\right)$ is characterized by a vector $\left(p_{i 1}, \ldots, p_{i m}\right)$ whose coordinates are the relative frequencies of each $\mathrm{O}$ chromosomal arrangement, with

$p_{i j} \geq 0, i=1, \ldots, 22, j=1, \ldots, m$

and

$\sum_{j=1}^{m} p_{i j}=1, i=1, \ldots, 22$

Thus, each vector represents a point in the genetic space. Mathematically, this genetic space constitutes a manifold with boundary of dimension $n=m-1$ (Balanyà et al. 2004).

We can define a distance between two populations $P_{i}=$ $\left(p_{i 1}, \ldots, p_{i k}\right)$ and $P_{j}=\left(p_{j 1}, \ldots, p_{j k}\right)$ by

$d\left(P_{i}, P_{j}\right)=\arccos \sum_{k=1}^{m} \sqrt{p_{i k} p_{j k}}$

where $d^{2}\left(P_{i}, P_{j}\right)$ is the Bhattacharyya distance (Bhattacharyya $1946)$ associated with an analyzed chromosome.

These proportions were transformed by $2 \sqrt{p_{i j}}$ which provides a very good Euclidean approximation to the Bhattacharyya distance (Balanyà et al. 2006). Then, a principal component analysis of the covariance matrix of the transformed proportions was computed, and a graphical display of the positions of the populations in two and three dimensions was obtained.

Finally, we repeated the principal component analysis using the same populations, but after excluding the $\mathrm{O}_{5}$ inversion. In America, the frequency of this inversion varies clinally with latitude and is completely associated with a lethal gene. Its relative abundance in America is rather high and could bias the overall pattern of lethals on the $\mathrm{O}$ chromosome.

\section{Results}

Viability tests

The viability distribution of flies homozygous for wild $\mathrm{O}$ chromosomes in both analyzed populations was bimodal, as is typical (Dobzhansky et al. 1977). The frequencies of lethal and semilethal chromosomes, as well as the genetic load (see Greenberg and Crow 1960) are given in Table 1. The separate frequencies of lethal and of semilethal genes are not significantly different between Santiago de Chile II and Puerto Montt: $\chi^{2}=1.60$-with Yates correction; $P$ value $0.206 ; \mathrm{df}=1$, for lethals, and $\chi^{2}=1.90$-with Yates correction; $P$-value $0.168 ; \mathrm{df}=1$, for semilethals, respectively. However, the frequencies of lethal plus semilethal genes are significantly different for these two 
Table 1 Frequency (in percentage) of lethal and semilethal $\mathrm{O}$ chromosomes and lethal load

\begin{tabular}{|c|c|c|c|c|c|}
\hline Population & $N$ & Lethals (L) & Semilethals (SL) & $\mathrm{L}+\mathrm{SL}$ & Genetic load \\
\hline Santiago de Chile II & 119 & $17.6 \pm 3.4$ & $3.4 \pm 1.7$ & $21.0 \pm 3.7$ & 0.194 \\
\hline Puerto Montt & 119 & $25.2 \pm 4.0$ & $8.4 \pm 2.5$ & $33.6 \pm 4.3$ & 0.290 \\
\hline Santiago de Chile I & 20 & $15.0 \pm 8.0$ & $5.0 \pm 4.9$ & $20.0 \pm 8.9$ & 0.163 \\
\hline Gilroy I & 111 & $14.4 \pm 3.3$ & $2.7 \pm 1.5$ & $17.1 \pm 3.6$ & 0.156 \\
\hline Gilroy II & 77 & $10.4 \pm 3.5$ & $6.5 \pm 2.8$ & $16.9 \pm 4.3$ & 0.110 \\
\hline Bellingham & 108 & $12.0 \pm 3.1$ & $1.9 \pm 1.3$ & $13.9 \pm 3.3$ & 0.128 \\
\hline Centralia & 65 & $16.9 \pm 4.6$ & $6.2 \pm 3.0$ & $23.1 \pm 5.2$ & 0.185 \\
\hline
\end{tabular}

$N=$ number of chromosomes

populations $\left(\chi^{2}=4.15\right.$-with Yates correction; $P$-value 0.042 ; df $=1)$. Furthermore, the frequencies of lethals and lethals plus semilethals are significantly different between Puerto Montt and the other American populations studied: $\chi^{2}=7.40$ - with Yates correction; $P$-value 0.0065 ; df $=6$, for lethals, and $\chi^{2}=12.78$-with Yates correction; $P$ value 0.0004 ; $\mathrm{df}=6$, for lethals plus semilethals, respectively. This last result could be attributed to the rather high frequencies of lethals and semilethals in Puerto Montt $(25.2 \pm 4.0$ and $8.4 \pm 2.5$, respectively).

\section{Chromosomal polymorphism}

The distribution of lethal genes among chromosomal arrangements in both Chilean populations studied is given in Table 2. The $\mathrm{O}_{5}$ and $\mathrm{O}_{\underline{3+4}+\underline{7}}$ arrangements are more common in Puerto Montt than in Santiago de Chile II. The $\mathrm{O}_{7}$ inversion is infrequent and was found only in one nonlethal chromosomal line from Santiago de Chile II and in one lethal line from Puerto Montt. The chromosomal polymorphism of the lethal and non-lethal chromosomal lines is significantly different in Santiago de Chile II $\left(\chi^{2}=27.09 ; \quad P\right.$-value $\left.<0.0001 ; \mathrm{df}=3\right)$ and in Puerto Montt $\left(\chi^{2}=33.70 ; P\right.$-value 0.0008; df $\left.=3\right)$. However, the

Table 2 O chromosomal polymorphism of non-lethal and lethal chromosomal lines from Santiago de Chile II and Puerto Montt

\begin{tabular}{|c|c|c|c|c|}
\hline \multirow{2}{*}{$\begin{array}{l}\text { Chromosomal } \\
\text { arrangement }\end{array}$} & \multicolumn{2}{|c|}{ Santiago de Chile II } & \multicolumn{2}{|c|}{ Puerto Montt } \\
\hline & $\begin{array}{l}\text { Non-lethal } \\
\text { lines }\end{array}$ & $\begin{array}{l}\text { Lethal } \\
\text { lines }\end{array}$ & $\begin{array}{l}\text { Non-lethal } \\
\text { lines }\end{array}$ & $\begin{array}{l}\text { Lethal } \\
\text { lines }\end{array}$ \\
\hline $\mathrm{O}_{\mathrm{st}}$ & 23 & 3 & 28 & 4 \\
\hline $\mathrm{O}_{5}$ & - & 5 & - & 10 \\
\hline $\mathrm{O}_{7}$ & 1 & - & - & 1 \\
\hline $\mathrm{O}_{\underline{3+4}}$ & 9 & - & 3 & - \\
\hline $\mathrm{O}_{\underline{3+4}+\underline{2}}$ & 36 & 3 & 25 & 3 \\
\hline $\mathrm{O}_{\underline{3+4}+\underline{7}}$ & 11 & 4 & 8 & 9 \\
\hline $\mathrm{O}_{\underline{3+4+8}}$ & 14 & 5 & 21 & 3 \\
\hline TOTAL & 94 & 20 & 85 & 30 \\
\hline
\end{tabular}

distribution of lethals among the chromosomal arrangements is not significantly different between Santiago de Chile II and Puerto Montt $\left(\chi^{2}=2.20 ; P\right.$-value 0.532; $\mathrm{df}=3$ ). Most probably, the association of lethal genes to some chromosomal inversions in these colonizing populations is due to the relatively recent founder event during the colonization. Furthermore, the frequency of some of the arrangements associated with lethal genes varies latitudinally (Prevosti et al. 1985, 1988, 1990; Balanyà et al. 2003), so that they can be rather frequent in some localities. This may explain the high frequency of lethal genes observed in Puerto Montt: the $\mathrm{O}_{5}$ inversion, which is always associated with a lethal gene in the American populations (Mestres et al. 1990, 1992, 1995, 2001), is common at this locality. To evaluate this hypothesis, we computed the correlation between the log transformed frequency of lethal genes and of $\mathrm{O}_{5}$ inversion in these seven American populations: the correlation was 0.847 and significant $(t=3.557 ; P$-value $=0.016)$.

In American populations, the distribution of lethal genes among the different $\mathrm{O}$ chromosome inversions is not random, as can be clearly observed in a multivariate principal component analysis. A graphical representation of the 11 populations with their corresponding samples of lethals is shown in Fig. 1a, where a final "L" in the population abbreviation denotes a lethal sample. The first and second axes explain $63.00 \%$ and $14.28 \%$ of the variability, respectively. Altogether, both axes explain $77.28 \%$ of the variability. The first axis denotes the founder effect, clearly separating the Palearctic and American populations (including the lethal samples): the chromosomal polymorphism is much richer in the Palearctic region than in America (Prevosti et al. 1985, 1988, 1990; Balanyà et al. 2003). Moreover, note that the Palearctic populations and their lethal samples are superimposed, whereas American ones are not: with the exception of Gilroy I, these populations and their corresponding lethal samples are clearly separated (Fig. 1a). However, as shown by a threedimensional representation (Fig. 1b), this lethal sample of Gilroy I is actually closer to the other lethal samples. 

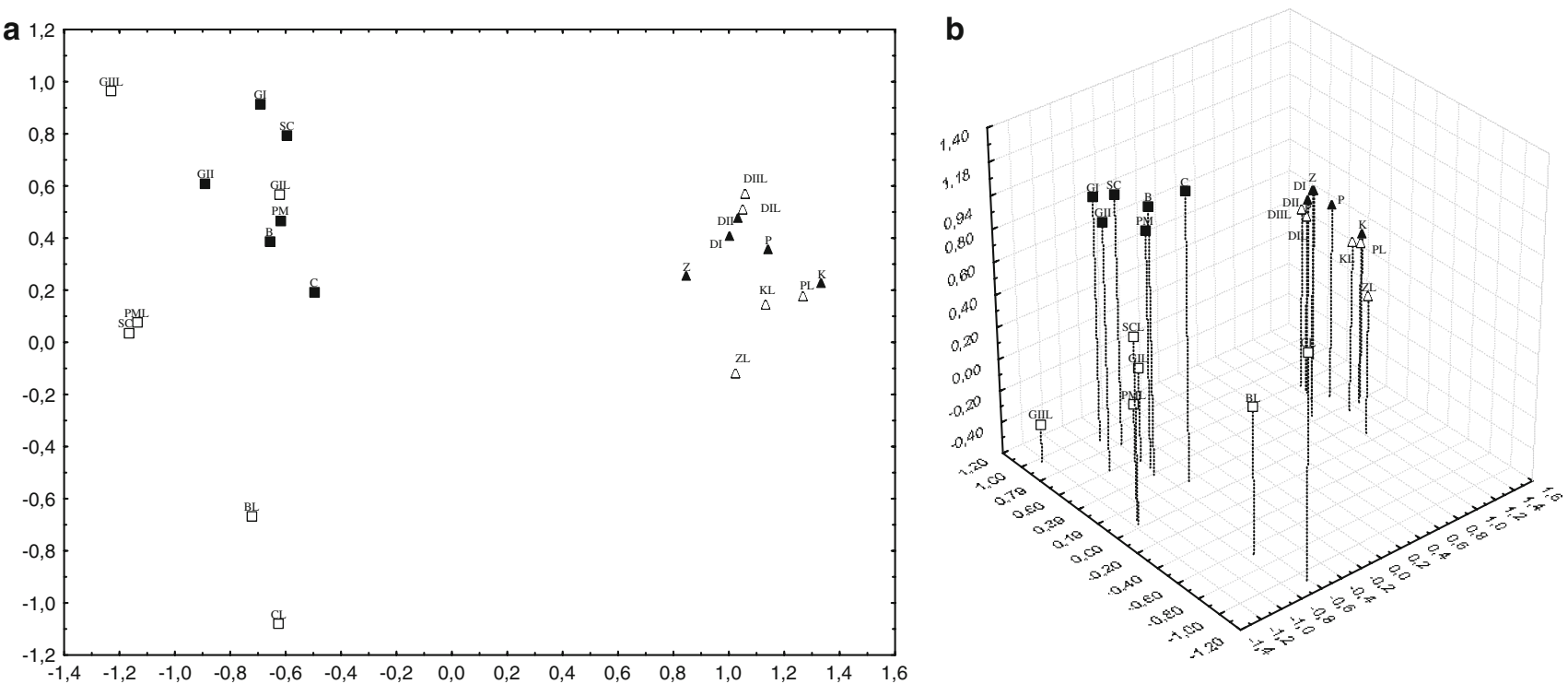

Fig. 1 Graphical representation of the principal component analysis in two (a) and three (b) dimensions for the 11 populations with their corresponding samples of lethals. Populations from the Palearctic region (filled triangles) are: Kamariste (K), Zanjic (Z), Petnica (P), Djerdap I (DI), and Djerdap II (DII). Corresponding lethal samples are denoted by adding a final "L" letter and by open triangles. Thus,

If the principal component analysis is repeated after excluding the $\mathrm{O}_{5}$ inversion (see Materials and Methods), the populations and lethal samples in the Americas become superimposed (Fig. 2a, b). The first and second axes now explain $61.68 \%$ and $16.72 \%$ of the variability, respectively. Altogether, both axes explain $78.40 \%$ of the variability. Thus, the complete association of a lethal gene with $\mathrm{O}_{5}$ inversion in the American populations changes the
KL means the lethal sample from Kamariste. Populations from America (filled squares) are: Santiago de Chile II (SC), Puerto Montt (PM), Gilroy I (GI), Gilroy II (GII), Centralia (C), and Bellingham (B). Corresponding lethal samples are denoted by adding a final " $L$ " letter and by open squares

differentiation of chromosomal polymorphism of whole samples with their lethal fraction.

Lethal allelism

As shown by the maximum likelihood approach with Wilks' approximation, the $k$ parameter differs significantly from the expected $2 / 3$ ratio in both analyzed populations
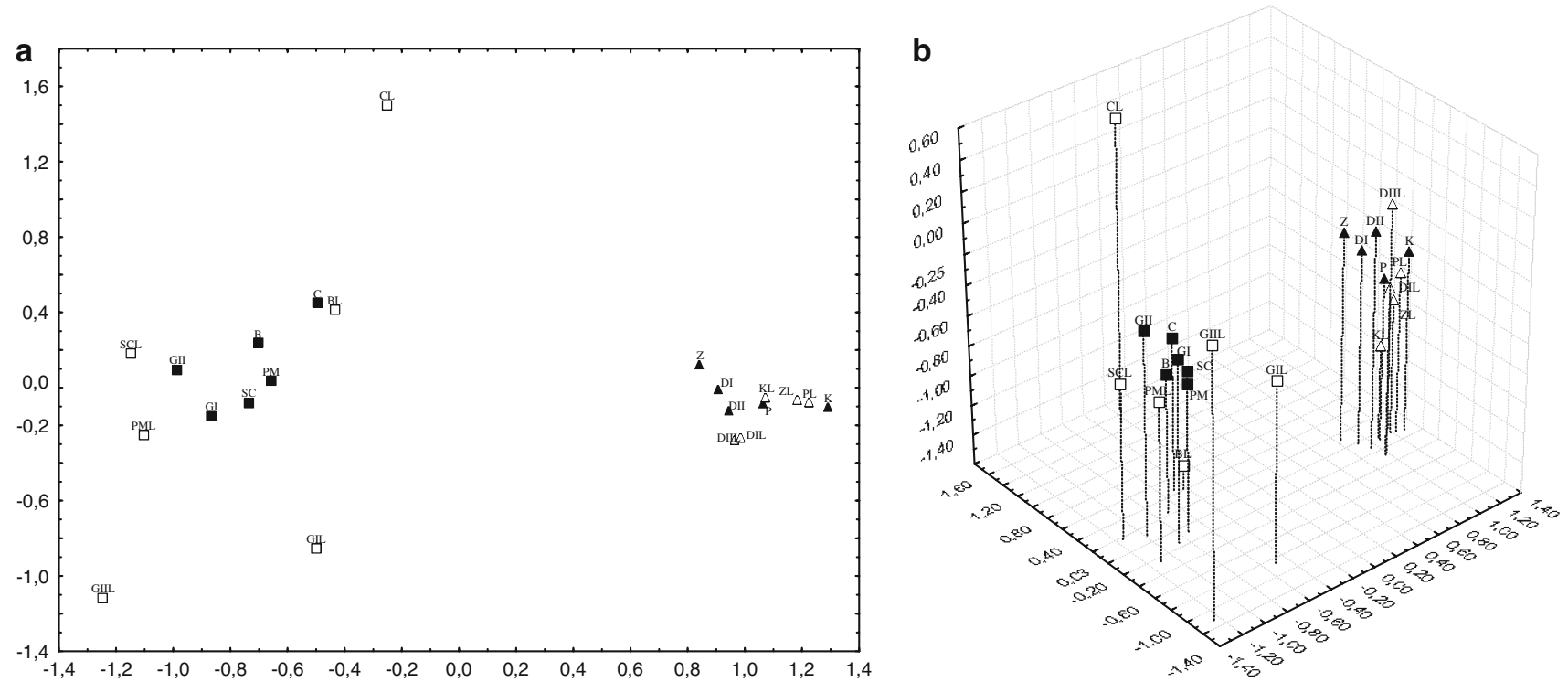

Fig. 2 Graphical representation in two (a) and three (b) dimensions of the principal component analysis for the 11 populations with their corresponding samples of lethals with the $\mathrm{O}_{5}$ inversion excluded 
(Santiago de Chile II: $k=0.995, P$-value $=0.047$; Puerto Montt: $k=3.208, P$-value $=0.0002$ ). Thus, lethal genes along the $\mathrm{O}$ chromosome are not distributed at random. As mentioned previously, the percentages of allelism have been corrected using the method proposed by Loukas et al. 1980, which transforms the SI + SII lethal chromosomes into SII lethal "equivalents." Because the distribution of lethal genes is non-random, we assumed all lethal genes in the $\mathrm{O}_{5}$ chromosome belong to type SII, and we have applied the correction proposed by Mestres and Serra (1999, see Materials and Methods).

All possible crosses between the lethal chromosomes, within and between populations, were carried out to ascertain allelism. Results of the intra-populational and inter-populational allelism tests are presented in Tables 3 and 4 , respectively. The complete data set is given in the Supplementary material (Tables S1-S5).

Several associations between lethal genes and chromosomal inversions have been previously found in American populations of D. subobscura (Mestres et al. 1990, 1992, 1995; Solé et al. 2000). As noted previously, one lethal gene is completely associated with the $\mathrm{O}_{5}$ inversion in all American samples analyzed. That is, the lethal gene is only found with the $\mathrm{O}_{5}$ and this inversion always carries this lethal. A different lethal gene is associated with the chromosomal arrangement $\mathrm{O}_{\underline{3+4}+\underline{7}}$. However, this association is

Table 3 Intra-populational frequencies of allelism in American D. subobscura populations

\begin{tabular}{lcc}
\hline Population & $\begin{array}{l}\text { Frequency } \\
\text { of allelism }\end{array}$ & $\begin{array}{l}\text { Corrected } \\
\text { frequency } \\
\text { of allelism }\end{array}$ \\
\hline Santiago de Chile II & $0.052 \pm 0.018$ & $0.048 \pm 0.017$ \\
Puerto Montt & $0.138 \pm 0.017$ & $0.073 \pm 0.009$ \\
Santiago de Chile I & - & - \\
Gilroy I & $0.075 \pm 0.024$ & $0.053 \pm 0.021$ \\
Gilroy II & $0.214 \pm 0.078$ & $0.135 \pm 0.051$ \\
Bellingham & $0.269 \pm 0.050$ & $0.341 \pm 0.060$ \\
Centralia & $0.182 \pm 0.052$ & $0.122 \pm 0.036$ \\
\hline
\end{tabular}

incomplete, the lethal gene is always found in the $\mathrm{O}_{\underline{3+4}+7}$, but this arrangement can have other lethal genes or even be free of lethals. The intra-populational lethal allelism of Santiago de Chile II (Table S1) is due to the lethal gene completely associated with the $\mathrm{O}_{5}$ inversion (chromosomal lines SC35, SC37, SC58, and SC174), to the lethal gene partially associated with the $\mathrm{O}_{\underline{3+4}+7}$ arrangement and previously observed in other American populations studied (SC105 and SC153), and with a new lethal gene (never observed in previous studies) found in two $\mathrm{O}_{\underline{3+4}+7}$ lethal chromosomal lines (SC52 and SC65).

The intra-populational allelism of Puerto Montt (Table S2) is due to the lethal gene invariably associated with the $\mathrm{O}_{5}$ inversion (PM14, PM18, PM20, PM41, PM61, PM63, PM113, PM119, PM140, and PM144), to the lethal gene partially associated with the $\mathrm{O}_{\underline{3}+4+\underline{7}}$ arrangement and found previously in the American continent (PM32, PM35, PM39, and PM46), and to this latter lethal gene, but carried by an $\mathrm{O}_{7}$ chromosomal line (PM57). The $\mathrm{O}_{7}$ alone is thought to be the result of a very rare recombination event between an $\mathrm{O}_{\underline{3+4}+\underline{7}}$ chromosome and an $\mathrm{O}_{\mathrm{st}}$ one. Most probably, the linkage disequilibrium for the inversions $\mathrm{O}_{\underline{3+4}}$ and $\mathrm{O}_{7}$ is due to an extreme reduction of crossing over in the region between them (Sperlich and Feuerbach-Mravlag 1974). Nevertheless, the presence of the same lethal gene in both types of chromosomal lines $\left(\mathrm{O}_{\underline{3+4}+\underline{7}}\right.$ and $\left.\mathrm{O}_{7}\right)$ indicates that recombination does take place, even if rarely.

The inter-populational allelism between Santiago de Chile II and Puerto Montt (Table S3) is mostly due to lethals carried by the $\mathrm{O}_{5}$ and $\mathrm{O}_{\underline{3+4}+\underline{7}}$ arrangements: all $\mathrm{O}_{5}$ chromosomes carry the same lethal gene, whereas $\mathrm{O}_{\underline{3+4}+7}$ chromosomes carrying the lethal gene partially associated are allelic among themselves. However, there is another case of allelism: the same lethal gene is present in two chromosomal lines $\mathrm{O}_{\underline{3+4}+2}$, one from each population. It could indicate the existence of gene flow among the Chilean populations. The inter-populational allelism test between Santiago de Chile II and the lethal chromosomal lines from previous studies (Mestres et al. 1990, 1992, 1995; Solé et al. 2000) presented only two kinds of allelic

Table 4 Inter-populational frequencies of allelism between Santiago de Chile II and Puerto Montt and the other American D. subobscura populations

\begin{tabular}{|c|c|c|c|c|}
\hline & \multicolumn{2}{|c|}{ Santiago de Chile II } & \multicolumn{2}{|l|}{ Puerto Montt } \\
\hline & Uncorrected & Corrected & Uncorrected & Corrected \\
\hline Santiago Chile II & - & - & $0.099 \pm 0.023$ & $0.060 \pm 0.008$ \\
\hline Gilroy I & $0.099 \pm 0.023$ & $0.097 \pm 0.023$ & $0.152 \pm 0.023$ & $0.130 \pm 0.020$ \\
\hline Gilroy II & $0.083 \pm 0.023$ & $0.063 \pm 0.018$ & $0.147 \pm 0.023$ & $0.103 \pm 0.017$ \\
\hline Bellingham & $0.120 \pm 0.021$ & $0.093 \pm 0.017$ & $0.186 \pm 0.020$ & $0.089 \pm 0.010$ \\
\hline Centralia & $0.111 \pm 0.026$ & $0.089 \pm 0.021$ & $0.177 \pm 0.025$ & $0.075 \pm 0.011$ \\
\hline
\end{tabular}


crosses, those in which the lethal gene was completely associated with $\mathrm{O}_{5}$ or was partially associated with $\mathrm{O}_{\underline{3+4+7}}$ (Table S4). Similar results are observed in the inter-populational allelism test between Puerto Montt and the other chromosomal lines (Table S5), with the exception of the presence of a particular case of allelism, between the lethal chromosomal line PM5 $\left(\mathrm{O}_{\underline{3+4}+\underline{2}}\right)$ and the $\mathrm{C} 105\left(\mathrm{O}_{5}\right)$ (from the population of Centralia). The most probable explanation is that the $\mathrm{C} 105$ chromosomal line carries two lethals, one that is typically associated with $\mathrm{O}_{5}$ and another new one, which is allelic with that of line PM5. If we assume that these two allelic lethals are not identical by descent, we can estimate the value $p_{\infty}$ (the rate of allelism of independently arisen lethal genes) using mathematical expression (1) of Loukas et al. 1980. The value obtained is $p_{\infty}=0.0013$, which is of the same order of magnitude than previous estimates in the $\mathrm{O}$ chromosome of $D$. subobscura $\left(p_{\infty}=0.0041\right)$ (Loukas et al. 1980) and in chromosome II of D. melanogaster $\left(p_{\infty}=0.0029\right)$ (Begon et al. 1985).

Overall, out of 99 lethal genes studied in the American continent, 49 proved to be different. The most common lethal gene is completely associated with $\mathrm{O}_{5}$ inversion: this lethal has been detected 32 times on the American continent $(32.3 \%)$. Another common lethal gene is partially associated with the $\mathrm{O}_{\underline{3+4}+\underline{7}}$ arrangement (found 15 times), plus another copy located in $\mathrm{O}_{7}$ (thus, 16 times in total). Several other lethal genes have been found sporadically: one located in $\mathrm{O}_{\underline{3+4}+\underline{2}}$ chromosomal lines (detected two times, once each in Gilroy I and in Santiago de Chile I), another in the same arrangement and also detected twice (one in Gilroy I and one in Gilroy II), another in the same arrangement and found twice (one in Santiago de Chile II and one in Puerto Montt), and finally one lethal gene detected twice, once in an $\mathrm{O}_{\underline{3+4}+2}$ arrangement of Puerto Montt and once in an $\mathrm{O}_{5}$ chromosomal line from Centralia. In all other cases (43), lethal genes have been observed only once in American populations (43.4\%).

\section{Population parameters}

In Table 5, we present, for all American populations so far analyzed, estimates of the effective population size $\left(N_{e}\right)$ based on the incidence of intra-populational allelism, as well as estimates of fitness reduction in heterozygotes by carrying lethal chromosomes $\left(h\right.$ and $h_{e}$ ). Two different $N_{e}$ estimates are given for each population (see Materials and Methods), based on two different estimates of the number of loci that can mutate to a lethal allele $(n=238$ or 307). $N_{e}$ values have been estimated primarily for purposes of comparing populations. In general, the values of the effective population size of Santiago de Chile II and Puerto Montt are similar to those previously observed in the
Table 5 Population parameters derived from intra-populational lethal allelism tests

\begin{tabular}{|c|c|c|c|c|c|c|}
\hline \multirow[t]{2}{*}{ Population } & \multicolumn{3}{|c|}{$n=238$} & \multicolumn{3}{|c|}{$n=307$} \\
\hline & $h$ & $h_{e}$ & $N_{e}$ & $h$ & $h_{e}$ & $N_{e}$ \\
\hline Gilroy I & 0.0166 & 0.0084 & 2145 & 0.0215 & 0.0132 & 1830 \\
\hline Gilroy II & 0.0140 & -0.0053 & 847 & 0.0181 & -0.0012 & 651 \\
\hline Bellingham & 0.1121 & 0.1051 & 212 & 0.1447 & 0.1376 & 164 \\
\hline Centralia & 0.0129 & -0.0060 & 966 & 0.0166 & -0.0022 & 742 \\
\hline $\begin{array}{l}\text { Santiago de Chile } \\
\text { II }\end{array}$ & 0.0123 & 0.0006 & 1756 & 0.0159 & 0.0042 & 1338 \\
\hline
\end{tabular}

$\begin{array}{lllllll}\text { Puerto Montt } \quad 0.0082 & -0.078 & 1949 & 0.0106 & -0.0054 & 1484\end{array}$

$n$ is the number of loci that can mutate to recessive lethals. $N_{e}$ is the effective population size. $h$ and $h_{\mathrm{e}}$ are the average fitness reduction in lethal heterozygotes according to Nei (1968) and Crow and Temin (1964), respectively. This estimates have been computed using $p_{\infty}=0.0041, \mu=10^{-5}$ and two different values for the number of lethal loci, $n=238$ (based on the number of bands detected in segment SII of standard polytene $\mathrm{O}$ chromosomes) and $n=307$ (estimated by using the number of bands detected within segment SII in stretched polytene chromosomes) (for details see Mestres et al. 1990; Mestres and Serra 1991)

American colonizing populations (Mestres et al. 1990, 1995; Solé et al. 2000) and lower than those estimated in the Palearctic region (Loukas et al. 1980; Mestres et al. 1990; Zivanovic et al. 2007). In America, the absolute values are biased owing to the high incidence of allelism, which in turn is a historical consequence of the small number of colonizers and the effect of natural selection over several inversions, producing small $N_{e}$ values (Ayala et al. 1989; Prevosti et al. 1989; Mestres et al. 1990, 1995, 2001).

\section{Discussion}

Associations between lethal genes and inversions

The distribution of lethal genes could depend on the inversions in those species with rich chromosomal polymorphism, such as D. subobscura. Two concepts must be defined, because they are not synonymous and can be confused: the association between a lethal gene and a chromosomal inversion, and the non-random distribution of lethal genes on the chromosome. First, an association exists if a lethal gene is always detected with a particular chromosomal inversion. This association is complete if the lethal gene is always located in the same inversion, and if this inversion always contains the lethal gene; or it is incomplete if the lethal gene is located always in the same inversion, but if this inversion can carry other lethal genes or even be free of them. The second concept is based on the fact that lethal genes tend to accumulate in chromosomal 
inversions, especially in smaller inversions. Lethal genes located inside small inversions can be different and vary in frequency depending on evolutionary forces. Thus, an observed non-random distribution of lethal genes on the chromosome does not necessarily imply that associations exist: a single inversion may accumulate different lethal alleles. Different associations between lethal genes and inversions have been described in D. pseudoobscura (Epling et al. 1961; Dobzhansky et al. 1963; Mayhew et al. 1966) and D. melanogaster, both in natural populations (Coyne et al. 1991) and in selected lines (García-Dorado and López-Fanjul 1987). Non-random distributions of lethal genes on the chromosomes were detected in D. pseudoobscura (Dobzhansky et al. 1963; Mayhew et al. 1966; Crumpacker and Salceda 1969; Bryant 1976), in long-term selected lines of D. melanogaster (Albornoz and Domínguez 1994), in D. albomicans (Chang and Lin 1995; Chang et al. 1996; Yang et al. 2002), and possibly in D. nasuta (Kumar and Gupta 1989).

Some hypotheses explain the relation between lethal genes and chromosomal inversions. Thus, Dobzhansky et al. (1963) and Crumpacker and Salceda (1969) suggested that selection for high average fitness would result in the association of deleterious recessive genes with rare chromosomal arrangements. Muller (1964), Felsenstein (1974), James (1992) and Yang et al. (2002) proposed that when an inversion - or other rearrangements that suppress recombination-appears in a population, lethal alleles can accumulate on this inverted chromosome due to lack of recombination. If the population remains large, the chromosome carrying the inversion will reach a mutationselection balance. On the other hand, if the population is small the bottleneck effect occurs, and the frequency of heterokaryotypes increases because of inbreeding depression (producing an elimination of homokaryotypes).

In the Palearctic populations of $D$. subobscura studied to date, lethal genes are never associated with chromosomal inversions (Mestres et al. 1990; Zivanovic et al. 2000). Nonetheless, several Balkan populations (Petnica, Zanjic, and Djerdap) show a non-random distribution of lethal genes (Zivanovic et al. 2007). However, these lethal genes do not cluster inside or at the boundaries of particular chromosomal arrangements, as evidenced by the similarity of the chromosomal polymorphism of the whole samples and their lethal fraction (Fig. 1a, b). In the American populations, the situation is dramatically different. Several associations were detected soon after the colonization: the complete association between a lethal gene and the $\mathrm{O}_{5}$ inversion, and the incomplete associations between a lethal gene and the $\mathrm{O}_{\underline{3+4}+\underline{7}}$ arrangements, and another lethal gene and the $\mathrm{O}_{\underline{3+4}+\underline{2}}$ arrangement (Mestres et al. 1990, 1992, 1995). These associations and the non-random distribution of lethal genes on the $\mathrm{O}$ chromosome (Mestres and Serra
1999; Solé et al. 2000) are thought to be a consequence of the founder event. The bottleneck was strong: in fact, only 4-11 flies are estimated to have colonized the New World (Brncic et al. 1981; Prevosti et al. 1989; Rozas and Aguadé 1991; Pascual et al. 2001, 2007; Mestres et al. 2004, 2005).

The first two associations (those with the $\mathrm{O}_{5}$ and $\mathrm{O}_{\underline{3+4}+7}$ inversions) have persisted in both North and South America. Interestingly, inversions carrying these lethal genes seem heterotic, which may explain their persistence (Mestres et al. 2001). Our new samples demonstrate that both associations persist in South America, as they have been found in collections from Santiago de Chile II and from Puerto Montt in 1999 (Tables S4 and S5). The association of a lethal gene with the $\mathrm{O}_{5}$ inversion seems responsible for the overall high lethal frequency in Puerto Montt. Furthermore, we have detected a significant correlation between the frequency of this inversion and the frequency of lethal genes in American populations. When the principal component analysis is repeated, excluding the $\mathrm{O}_{5}$ inversion in the 11 general samples and in the corresponding lethal fraction, both kinds of samples mix together.

Interestingly, the incomplete association between a lethal gene and the $\mathrm{O}_{\underline{3+4}+\underline{2}}$ arrangement, which was detected in the early samples from both North and South America (Mestres et al. 1990, 1992), is no longer found. In all American analyses (Mestres et al. 1990, 1992, 1995; Solé et al. 2000), including the present one, $16 \mathrm{O}_{\underline{3+4+2}}$ lethal chromosomal lines have been found, but this particular association has not been found since 1988 (Mestres et al. 1992). We have carried out a resampling test to evaluate whether this lethal has probably disappeared in America. Using either the overall frequency of this lethal gene in the early samples (0.1053), or its minimum frequency in those samples $(0.0625)$, we drew $10^{4}$ bootstrap samples with replacement to generate a sampling distribution. According to this analysis, the probabilities of finding this lethal in our samples from Santiago de Chile II are 0.8977 and 0.7256 , and from Puerto Montt are 0.9642 and 0.8576 . We hypothesize that this association was probably a consequence of the founder event and has been lost, probably due to natural selection or genetic drift.

\section{Gene flow between populations}

The frequency of inter-populational lethal gene allelism generally decreases with distance (Wright et al. 1942; Wallace 1966; Paik and Sung 1969; Yokoyama 1979; Yamazaki et al. 1986). Nevertheless, gene flow can occur even over moderate or long distances. For example, an analysis of lethal genes in D. pseudoobscura suggested some gene flow between the populations in the San Jacinto mountains of California (moderate distances, between 15 
and $20 \mathrm{~km}$ ) (Wright 1978). Bryant (1976) concluded that those lethal genes allelic in D. pseudoobscura from four locations in Southern California were probably heterotic. In D. melanogaster, Golubovsky (1966) found a non-negligible lethal allelism among populations, despite their spatial isolation $(5 \mathrm{~km})$. Similar results were obtained for this species in Japan by Watanabe (1969). Yamazaki et al. (1986) found variations in rates of lethal allelism among different pairs of populations. In D. subobscura, Zivanovic et al. (2000) found different levels of inter-populational allelism rates between Balkan populations, with the difference increasing with the distance and isolation between them. The general conclusion is that gene flow (measured by the inter-populational lethal allelism) can also occur over moderate and even large distances: this observation is consistent with the results of direct analyses of dispersal rates in Drosophila (Slatkin 1985).

In the present study, the inter-populational allelism rate found between Puerto Montt and Santiago de Chile II, separated by $900 \mathrm{~km}$, was $0.0601 \pm 0.0080$, similar in magnitude to that obtained between North American populations separated by 1,300 km (Mestres et al. 1995; Solé et al. 2000). This is an order of magnitude higher than the rate estimated for independently arising lethal genes, which is $0.0041 \pm 0.0019$ for the $\mathrm{O}$ chromosome (Loukas et al. 1980) and $0.0029 \pm 0.0009$ for the second chromosome of D. melanogaster (Begon et al. 1985). The lethal genes responsible for the allelism between the Chilean populations analyzed were the lethal genes completely associated with the $\mathrm{O}_{5}$ inversion, the lethal gene partially associated with the $\mathrm{O}_{\underline{3+4}+\underline{7}}$ arrangement, and a lethal gene found once in both populations and located in an $\mathrm{O}_{\underline{3}+4+2}$ chromosome. The first two lethal genes are located in heterotic inversions (Mestres et al. 2001), and this explains their persistence in the populations. No information is available on the viability in the heterokaryotypic condition of the $\mathrm{O}_{\underline{3}+4+2}$ chromosome carrying the latter lethal gene. It probably appeared in one population and dispersed by gene flow among Chilean populations. An analysis of its persistence in the near future will elucidate its viability. Thus, the data on lethal gene allelism show that Chilean populations are not isolated and have gene flow between them, consistent with patterns seen in molecular data (Pascual et al. 2007).

New genetic variability in Chilean populations

At the beginning of the colonization, North and South American populations of D. subobscura had equivalent genetic compositions and thus probably derived from a single colonizing event (Latorre et al. 1986; Prevosti et al. 1988, 1989; Mestres et al. 1990, 1992, 2004, 2005; Rozas et al. 1990; Rozas and Aguadé 1991; Balanyà et al. 1994; Pascual et al. 2007). Nevertheless, North and South
American populations have been genetically isolated since the colonization (Mestres et al. 2005). The inter-populational lethal allelism test between the Chilean populations of the present study and those from North America showed the following cases of allelism: the lethal genes associated with the $\mathrm{O}_{5}$ and $\mathrm{O}_{\underline{3+4}+\underline{7}}$ inversions (being heterotic in both hemispheres), and for a lethal gene present in an $\mathrm{O}_{5}$ inversion (chromosomal line C105) from Centralia (North America) and in an $\mathrm{O}_{\underline{3+4}+2}$ arrangement (PM5) from Puerto Montt. The most probable explanation is that the C105 chromosomal line carries two lethals, one that is typically associated with the $\mathrm{O}_{5}$ inversion and another new one that is allelic with that of line PM5. This latter lethal is apparently new, because it has not been found in any $\mathrm{O}_{5}$ inversion previously studied in America. Another explanation is possible, however: this second lethal gene might have merely been in low frequency and hence not detected in previous studies with the American populations. In this case, the $\mathrm{C} 105$ chromosomal line would have received this second lethal gene by recombination from another chromosome. If so, we have to assume that this lethal was probably present in the initial sample of colonizers, because we detect it in both North America (in C105) and South America (in PM5). Furthermore, it was not detected in the early studies, which makes the explanation based on recombination less likely. Thus, assuming an independent origin and following Loukas et al. (1980), the $p_{\infty}$ (the rate of independently arising lethal genes) value was obtained $\left(p_{\infty}=0.0013\right)$. This value is in agreement with the previous estimates of this parameter for the $\mathrm{O}$ chromosome of D. subobscura (Loukas et al. 1980).

New genetic variability is being generated by mutation and recombination and will be the substrate for evolution of the American populations. In the present study, we have observed new lethal genes that have likely arisen by mutation but have been detected only once. Their most probable fate, if they are not located in an adaptive complex (i.e., an inversion), is to be eliminated by natural selection or genetic drift.

Recombination has also been detected in the $\mathrm{O}_{7}$ inversion. The presence of the same lethal gene in this inversion and in the $\mathrm{O}_{3+4+7}$ implies that the $\mathrm{O}_{7}$ inversion arose by recombination. This scenario had been suggested previously (Sperlich and Feuerbach-Mravlag 1974), but the shared lethal provides confirmation.

Due to the rich chromosomal polymorphism for inversions in D. subobscura, recombination is complex and extremely low frequencies or even absence of recombination can be observed between inversions separated far from each other on the chromosome (Krimbas and Zouros 1969; Sperlich and Feuerbach-Mravlag 1974; Mestres et al. 1998). Epistatic interactions between $\mathrm{O}_{7}$ and $\mathrm{O}_{3+4}$ inversions could be responsible for recombination suppression. This is likely why the $\mathrm{O}_{7}$ inversion alone is rare in natural populations 
(Krimbas and Zouros 1969; Sperlich and FeuerbachMravlag 1974). With regard to the general question of the degree of genetic exchange in this species, in American populations and using the nucleotide sequence of the $O d h$ gene, genetic exchange has been observed between the arrangements $\mathrm{O}_{\underline{3+4}}, \mathrm{O}_{\underline{3+4+8}}$, and $\mathrm{O}_{\text {st }}$ (in which this gene is not included), but associations between some $O d h$ haplotypes and the chromosomal inversions $\mathrm{O}_{5}$ and $\mathrm{O}_{\underline{3+4}+\underline{7}}$ were also found (Odh gene is located inside the $\mathrm{O}_{5}$ and $\mathrm{O}_{7}$ inversions) (Mestres et al. 2004). In Palearctic populations, gene conversion is one mechanism by which genetic information can be transferred between naturally occurring inversions (Rozas and Aguadé 1994). Co-adapted gene complexes are maintained either by the elimination of recombinant chromosomes through natural selection or by the absence of double crossovers inside some inversions (Munté et al. 2005). This lack of recombination could explain the persistence of the lethal genes in the heterotic inversions $\mathrm{O}_{5}$ and $\mathrm{O}_{\underline{3+4}+7}$ in American populations of D. subobscura.

\section{Conclusions}

An analysis of lethal gene variation over time has provided evidence of evolution in Chilean populations of $D$. subobscura. Several lethal genes (some of them non-randomly distributed along the chromosome) have been found only once: these probably arose locally by mutation and have (or will be) eliminated by selection or genetic drift. Some lethal genes that were temporally associated with chromosomal inversions during the founder event seem to have disappeared, whereas others have persisted as a result of their linkage to a presumed co-adapted complex. Finally, lethal genes have demonstrated the existence of gene flow and genetic recombination in these populations.

Acknowledgements We thank to P. Araúz, L. Abad, I. Giménez, S. Jurado, L. Llacuna, M. Pastor, and M. Sanchis for their help in obtaining the lethal chromosomal lines and in the analyses of allelism. This work was supported by grants BOS2003-05904-C02-02 and CGL2006-13423-C02-02 of M.E.C. (Spain) to LS, SGR2005 00995 from Generalitat de Catalunya (Spain), and by NSF grant IOB 0416843 to $\mathrm{RBH}$

\section{References}

Albornoz J, Domínguez A (1994) Inversion polymorphism and accumulation of lethals in selected lines of D. melanogaster. Heredity 73:92-97. doi:10.1038/hdy.1994.103

Ayala FJ, Serra L, Prevosti A (1989) A grand experiment in evolution: the D. subobscura colonization of the Americas. Genome 31:246-255

Balanyà J, Segarra C, Prevosti A, Serra L (1994) Colonization of America by D. subobscura: the founder event and a rapid expansion. J Hered 85:427-432
Balanyà J, Serra L, Gilchrist GW, Huey RB, Pascual M, Mestres F et al (2003) Evolutionary pace of chromosomal polymorphism in colonizing populations of D. subobscura: an evolutionary time series. Evolution 57:1837-1845

Balanyà J, Solé E, Oller JM, Sperlich D, Serra L (2004) Long-term changes in chromosomal inversion polymorphism of $D$. subobscura. II. European populations. J Zool Syst Evol Res 42:191-201. doi: 10.1111/j.1439-0469.2004.00274.x

Balanyà J, Oller JM, Huey RB, Gilchrist GW, Serra L (2006) Global genetic change tracks global climatic warning in D. subobscura. Science 313:1773-1775. doi:10.1126/science.1131002

Begon M, Chadburn R, Bishop JA, Keill C (1985) Genetic variation in a semi-natural Drosophila population after a bottleneck. I. Lethals, their allelism and effective population size. Genetica 66:11-20. doi:10.1007/BF00123601

Bhattacharyya A (1946) On a measure of divergence of two multinominal populations. Sankhya 7:401-406

Brncic D, Prevosti A, Budnik M, Monclús M, Ocaña J (1981) Colonization of D. subobscura in Chile. I. First population and cytogenetic studies. Genetica 56:3-9. doi:10.1007/BF00126923

Brussard PF (1984) Geographic patterns and environmental gradients: the central-marginal model in Drosophila revisited. Annu Rev Ecol Syst 15:25-64. doi:10.1146/annurev.es.15.110184.000325

Bryant SH (1976) The frequency and allelism of lethal chromosomes in isolated desert populations of D. pseudoobscura. Genetics 84:777-786

Chang H, Lin FJ (1995) The interaction between chromosomal inversion and recessive lethals in D. albomicans. Zool Stud 34:47-54

Chang H, Lan SF, Lin FJ (1996) Population significance of high recessive lethals in D. albomincans. Zool Stud 35:138-145

Coyne JA, Aulard S, Berry A (1991) Lack of underdominance in a naturally occurring pericentric inversions in D. melanogaster and its implications for chromosome evolution. Genetics 129:791-802

Crow JF, Temin RG (1964) Evidence for the partial dominance of recessive lethal genes in natural populations of Drosophila. Am Nat 98:21-33. doi:10.1086/282298

Crumpacker DW, Salceda VM (1969) Chromosomal polymorphism and genetic load in D. pseudoobscura. Genetics 61:859-873

Dobzhansky T, Wright S (1941) Genetics of natural populations. V. Relations between mutation rate and accumulation of lethals in populations of D. pseudoobscura. Genetics 26:23-51

Dobzhansky Th, Hunter AS, Pavlovsky O, Spassky B, Wallace B (1963) Genetics of natural populations. XXXI. Genetics of an isolated marginal population of D. pseudoobscura. Genetics 48:91-103

Dobzhansky T, Ayala FJ, Stebbins GL, Valentine JW (1977) Evolution. Freeman, San Francisco

Epling C, Tinderholt VE, Mattoni RHT (1961) Frequencies and allelism of lethal factors within and between gene arrangements. Evolution 15:447-454. doi:10.2307/2406312

Felsenstein J (1974) The evolutionary advantage of recombination. Genetics 78:737-756

García-Dorado A, López-Fanjul C (1987) Balanced polymorphism at the selection limit in D. melanogaster. J Hered 78:110-111

Golubovsky MD (1966) Distribution and allelism of autosomal lethals in two isolated subpopulations of a natural population of $D$. melanogaster from Uman (the Ukraine). Genetika 11:89-99

Greenberg R, Crow FJ (1960) A comparison of the effect of lethal and detrimental chromosomes from Drosophila populations. Genetics 45:1153-1168

James SH (1992) Inbreeding, self-fertilization, lethal genes and genomic coalescence. Heredity 68:449-456

Krimbas CB (1993) D. subobscura: biology, genetics and inversion polymorphism. Verlag Dr Kovac, Hamburg 
Krimbas CB, Zouros E (1969) Crossing-over suppression between linked but non-overlapping inversions in D. subobscura. Drosoph Inf Serv 44:71

Kumar A, Gupta JP (1989) Gene frequencies in natural and laboratory populations of D. nasuta. Hereditas 110:1-5. doi:10.1111/ j.1601-5223.1989.tb00410.x

Latorre A, Moya A, Ayala FJ (1986) Evolution of mitochondrial DNA in D. subobscura. Proc Natl Acad Sci USA 83:8649-8653. doi:10.1073/pnas.83.22.8649

Loukas M, Krimbas CB, Sourdis J (1980) The genetics of D. subobscura populations. XIII. A study of lethal allelism. Genetica 54:197-207. doi:10.1007/BF00055992

Mayhew SH, Kato SK, Ball FM, Epling C (1966) Comparative studies of arrangements within and between populations of D. pseudoobscura. Evolution 20:646-662. doi:10.2307/2406598

Mestres F, Serra L (1991) Lethal allelism in D. subobscura. Difficulties in the estimation of certain population parameters. Z Zool Syst Evolutionforsch 29:264-279

Mestres F, Serra L (1999) Distribution of lethal genes and their allelism in the $\mathrm{O}$ chromosome of D. subobscura. J Zoolog Syst Evol Res 37:7-11. doi:10.1046/j.1439-0469.1999.95091.x

Mestres F, Pegueroles G, Prevosti A, Serra L (1990) Colonization of America by $D$. subobscura: lethal genes and the problem of the $\mathrm{O}_{5}$ inversion. Evolution 44:1823-1836. doi:10.2307/2409511

Mestres F, Balanyà J, Segarra C, Prevosti A, Serra L (1992) Colonization of America by $D$. subobscura: analysis of the $\mathrm{O}_{5}$ inversions from Europe and America and their implications for the colonizing process. Evolution 46:1564-1568. doi:10.2307/2409960

Mestres F, Serra L, Ayala FJ (1995) Colonization of the Americas by D. subobscura: lethal-gene allelism and association with chromosomal arrangements. Genetics 140:1297-1305

Mestres F, Sanz J, Serra L (1998) Chromosomal structure and recombination between inversions in D. subobscura. Hereditas 128:105-113. doi:10.1111/j.1601-5223.1998.00105.x

Mestres F, Balanyà J, Arenas C, Solé E, Serra L (2001) Colonization of America by D. subobscura: heterotic effect of chromosomal arrangements revealed by the persistence of lethal genes. Proc Natl Acad Sci USA 98:9167-9170. doi:10.1073/pnas.161265998

Mestres F, Abad L, Sabater-Muñoz B, Latorre A, Serra L (2004) Colonization of America by D. subobscura: association between Odh gene haplotypes, lethal genes and chromosomal arrangements. Genes Genet Syst 79:233-244. doi:10.1266/ggs.79.233

Mestres F, Balanyà J, Pascual M, Arenas C, Solé E, Serra L (2005) Lethal genes and the colonization of America by D. subobscura. Curr Top Genet 1:31-55

Muller HJ (1964) The relation of recombination to mutational advance. Mutat Res 43:165-229

Munté A, Rozas J, Aguadé M, Segarra C (2005) Chromosomal inversion polymorphism leads to extensive genetic structure: a multilocus survey in D. subobscura. Genetics 169:1573-1581. doi: 10.1534 /genetics. 104.032748

Nei M (1968) The frequency distribution of lethal chromosomes in finite populations. Proc Natl Acad Sci USA 60:517-524. doi: 10.1073/pnas.60.2.517

Paik YK, Sung KC (1969) Behavior of lethals in D. melanogaster populations. Jpn J Genet 44(Suppl 1):180-192

Pascual M, Aquadro CF, Soto V, Serra L (2001) Microsatellite variation in colonizing and Palearctic populations of D. subobscura. Mol Biol Evol 18:731-740

Pascual M, Chapuis MP, Mestres F, Balanyà J, Huey RB, Gilchrist GW et al (2007) Introduction history of D. subobscura in the New World: a microsatellite-based survey using ABC methods. Mol Ecol 16:3069-3083. doi:10.1111/j.1365-294X.2007.03336.x

Pfriem P, Sperlich D (1982) Wild O chromosomes of D. subobscura from different geographic regions have different effects on viability. Genetica 60:49-59. doi:10.1007/BF00121457
Prevosti A, Serra L, Ribó G, Aguadé M, Sagarra E, Monclús M et al (1985) The colonization of D. subobscura in Chile. II. Clines in the chromosomal arrangements. Evolution 39:838-844. doi: $10.2307 / 2408683$

Prevosti A, Ribó G, Serra L, Aguadé M, Balanyà J, Monclús M et al (1988) Colonization of America by D. subobscura: experiment in natural populations that supports the adaptive role of chromosomal inversion polymorphism. Proc Natl Acad Sci USA 85:5597-5600. doi:10.1073/pnas.85.15.5597

Prevosti A, Serra L, Aguadé A, Ribó G, Mestres F, Balañá J et al (1989) Colonization and establishment of the Palearctic species D. subobscura in North and South America. In: Fontdevila A (ed) Evolutionary biology of transient unstable populations. Springer, Berlin, pp 114-129

Prevosti A, Serra L, Segarra C, Aguadé A, Ribó G, Monclús M (1990) Clines of chromosomal arrangements of D. subobscura in South America evolve closer to Old World patterns. Evolution 44:218 221. doi: $10.2307 / 2409539$

Rozas J, Aguadé M (1991) Using restriction-map analysis to characterize the colonization process of D. subobscura on the American continent. I. rp49 region. Mol Biol Evol 8:447-457

Rozas J, Aguadé M (1994) Gene conversion is involved in the transfer of genetic information between naturally occurring inversions in Drosophila. Proc Natl Acad Sci USA 91:11517-11521. doi: 10.1073/pnas.91.24.11517

Rozas J, Hernández M, Cabrera CV, Prevosti A (1990) Colonization of America by D. subobscura: effect of the founder event on the mitochondrial DNA polymorphism. Mol Biol Evol 7:103-109

Saura A, Johansson B, Eriksson E, Kohonen-Corish M (1990) Genetic load in northern populations of D. subobscura. Hereditas 112:283-287. doi:10.1111/j.1601-5223.1990.tb00068.x

Saura A, Johansson B, Lokki J, Kohonen-Corish M (1998) Genetic load in marginal populations of D. subobscura. Hereditas 129:283-286. doi:10.1111/j.1601-5223.1998.00283.x

Slatkin M (1985) Gene flow in natural populations. Annu Rev Ecol Syst 16:393-430. doi:10.1146/annurev.ecolsys.16.1.393

Solé E, Mestres F, Balanyà J, Arenas C, Serra L (2000) Colonization of America by $D$. subobscura: spatial and temporal lethal-gene allelism. Hereditas 133:65-72. doi:10.1111/j.1601-5223.2000. 00065.x

Sperlich D, Feuerbach-Mravlag H (1974) Epistatic gene interaction, crossing over and linked and unlinked inversions in $D$. subobscura. Evolution 28:67-75. doi:10.2307/2407239

Sperlich D, Feuerbach-Mravlag H, Lange P, Michaelidis A, PentzosDaponte A (1977) Genetic load and viability distribution in central and marginal populations of $D$. subobscura. Genetics 86:835-848

Townsend JI (1952) Genetics of marginal populations of $D$. willistoni. Evolution 6:428-442. doi:10.2307/2405705

Wallace B (1966) Distance and the allelism of lethals in a tropical population of D. melanogaster. Am Nat 100:565-578. doi: $10.1086 / 282450$

Watanabe TK (1969) Frequency of deleterious chromosomes and allelism between lethal genes in Japanese natural populations of D. melanogaster. Jpn J Genet 44:171-177. doi:10.1266/jjg.44.171

Wright S (1978) Evolution and the Genetics of populations. IV. Variability within and among natural populations. The University of Chicago Press, Chicago

Wright S, Dobzhansky Th, Hovanitz W (1942) Genetics of natural populations. VII. The allelism of lethals in the third chromosome of D. pseudoobscura. Genetics 27:363-394

Yamazaki T, Choo J, Watanabe TK, Takahata N (1986) Gene flow in natural populations of $D$. melanogaster with special reference to lethal allelism rates and protein variation. Genetics 113:73-89

Yang YY, Lin FJ, Chang H (2002) Comparison of recessive lethal accumulation in inversion-bearing and inversion-free chromosomes in Drosophila. Zool Stud 41:271-282 
Yokoyama S (1979) The rate of allelism of lethal genes in a geographically structured population. Genetics 93:245-262

Zivanovic G, Marinkovic D (2003) Viabilities of originally natural Ochromosomal inversion homo- and heterokaryotypes in $D$. subobscura. Hereditas 139:128-142. doi:10.1111/j.1601-5223. 2003.01770.x

Zivanovic G, Andjelkovic M, Marinkovic D (2000) Genetic load and coadaptation of chromosomal inversions. II. O-chromosomes in
D. subobscura populations. Hereditas 133:105-113. doi:10.1111/ j.1601-5223.2000.00105.x

Zivanovic G, Arenas C, Mestres F (2007) The genetic structure of Balkan populations of D. subobscura. Hereditas 144:120-128. doi:10.1111/j.2007.0018-0661.02008.x 